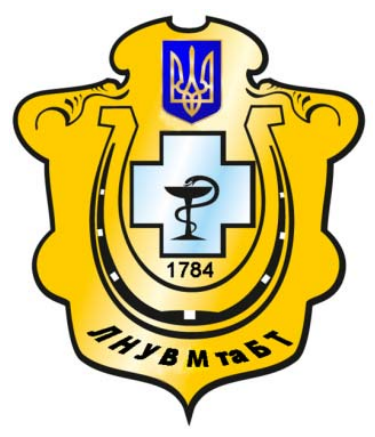

Науковий вісник Львівського національного університету ветеринарної медицини та біотехнологій імені С.3. Гжицького

Scientific Messenger of Lviv National University of Veterinary Medicine and Biotechnologies named after S.Z. Gzhytskyj

doi:10.15421/nvlvet7507

ISSN 2519-268X print

ISSN 2518-1327 online

$\underline{\text { http://nvlvet.com.ua/ }}$

УДК 637.5(075.8)

\title{
Визначення токсичності люпинового борошна і дивосилу та функціональних котлет 3 їх вмістом
}

\author{
М.З. Паска, О.Б. Маслійчук \\ maria_pas@ukr.net, olia_maruniak@ukr.net \\ Львівський національний університет ветеринарної медиџини та біотехнологій імені С.3. Гжицького, \\ вул. Пекарська, 50, м. Львів, 79010, Україна
}

На сьогодні, надзвичайно гостро постає проблема екологічно чистого, раціонального, збалансованого харчування. Оскільки, конщепџія сучасного харчування є не просто модною тенденцією, і велінням часу, то доцільно виведення на ринок нових функиіональних продуктів із заданими оздоровчо-профілактичними властивостяли. Харчування всіх груп населення України є важливим фактором, ще в значній мірі визначає здоров'я начії. На білих мишах було проведено вивчення токсичності люпинового борошна, кореня дивосилу та функиіональних котлет щзо містять у складі 5\%, 10\%, 15\% люпинового борошна із заміною м'ясної частини та 0,5\% дивосилу, як пряно-ароматичної добавки. Досліджено, щьо люпинове борошно та дивосил не викликають катарального або геморагічного запалення шллункво-кишкового тракту, та загибель мишей, отож є нетоксичні. При згодовуванні мишам котлет з 10\% вмістом люпинового борошна та 0,5\% дивосилу встановлено, що при патологоанатомічному розтині макроскопічних змін в органах $i$ тканинах не виявлено, $P>0,05$, що є в межах норми та гематологічні дослідження крові мишей підтверджують, що даний продукт можна включати в раціон харчування людей.

Ключові слова: м'ясний фарш, люпинове борошно, дивосил, функиіональні котлети, токсичність продукту.

\section{Определение токсичности люпиновой муки и девясила и функциональных котлет с их содержимым}

\author{
М.3. Паска, О.Б. Маслийчук \\ maria_pas@ukr.net,olia_maruniak@ukr.net
}

\begin{abstract}
Львовский национальный университет ветеринарной медицины и биотехнологий имени С.3. Гжицкого, ул. Пекарская, 50, г. Львов, 79010, Украина
\end{abstract}

\begin{abstract}
На сегодня чрезвычайно остро стоит проблема экологически чистого, рационального, сбалансированного питания. Так, концепиия современного питания является не просто модной тенденцией, и велением времени, то целесообразно выведение на рынок новых функииональных продуктов с заданными лечебно-профилактическими свойствами. Питания всех груп населения Украины является важным фактором, в значительной степени определяет здоровье начии. На бельх мышах было проведено изучение токсичности люпиновой муки, корня девясила и функциональных котлет содержащих в составе 5\%, 10\%, 15\% люпиновой муки с заменой мясного части и 0,5\% девясила, как пряно-ароматической добавки. Доказано, что люпиновая муку и девясил не вызывают катарального или геморрагического воспаления желудочно-кишечного тракта, $u$ гибель мышей, поэтому есть нетоксичны. При скармливании мышам котлет с 10\% содержанием люпиновой муки и 0,5\% девясила установлено, что при патологоанатомическом вскрытии макроскопических изменений в органах и тканях не обнаружено, $P>0,05$, что находится в пределах нормы и гематологические исследования крови мыпей подтверждают, что данный продукт можно включать в рачион питания людей.

Ключевые слова: мясной фарш, люпиновая муку, девясил, функииональные котлеты, токсичность продукта.
\end{abstract}

Citation:

Paska, M.Z., Masliichuk, O.B. (2017). Determination of toxicity of lupin flour and elecampane fnd functional cutlet with their content. Scientific Messenger LNUVMBT named after S.Z. Gzhytskyj, 19(75), 35-39. 


\title{
Determination of toxicity of lupin flour and elecampane fnd functional cutlet with their content
}

\author{
M.Z. Paska, O.B. Masliichuk \\ maria_pas@ukr.net, olia_maruniak@ukr.net \\ Lviv national university of veterinary medicine and biotechnologies named after S. Gzhytskyj, \\ Pekarska Str., 50, Lviv, 79010, Ukraine
}

\begin{abstract}
The well-balanced healthy ecologic-clean nutrition is a hot issue nowadays. Since the concept of modern nutrition is not just a fashionable trend or the trend of time, it is advisable to market for new products with desired functional health and preventivehealth qualities. Nutrition is an important factor which considerably defines the nation's state of health. White mice were studied the impact of lupin flour toxcity, Elecampane root and functional cutlets containing in the 5\%, 10\%, 15\% of lupin flour with the replacement of meat and $0.5 \%$ of Elecampane as aromatic additives. For experiments on extracts used 5 white mice weighing 19-21 $g$, which were kept on a starvation diet for five hours for which the probe was injected once through the mouth into the stomach of $0.5 \mathrm{ml}$ of the extract. After 3 days of observation mice were put away with chloroform and spent mortem. For experiments on chops, they were injected into the daily diet, replacing them quantitatively feed a part of the diet. Feeding spent 10 days in a row. Mice were kept before the experiment five hours without food (water was not restricted). For experiment took 20 mice (10 control) which were daily clinical observed. The indicators of toxicity include loss of body weight, disorders of the gastrointestinal tract and central nervous system (excitation or inhibition, loss of coordination of movements, seizures, paralysis). Studied that lupin flour and Elecampane not cause catarrhal or hemorrhagic inflammation of the gastrointestinal tract of mice and death, so are non-toxic. In mice fed cutlets with 10\% content lupin flour and $0.5 \%$ Elecampane found that when mortem macroscopic changes in the organs and tissues were found, $P>0.05$, which is within normal limits and hematological blood tests confirmed the mice that This product can be included in the diet of people. Therefore lupin flour and Elecampane can enter into functional products to address the protein deficit and a full, preventive nutrition.
\end{abstract}

Key words: minced meat, lupin flour, Elecampane, functional cutlets, the toxicity of the product.

\section{Вступ}

Функціональні посічені м’ясні напівфабрикати гармонійно поєднують в собі високі смакові якості, харчову цінність 3 позитивними функціональними властивостями і забезпечують позитивний вплив на здоров'я людини. При цьому вони призначені широкій аудиторії споживачів і можуть вживатися регулярно у складі нормального раціону харчування без якихнебудь особливих рекомендацій.

На Всесвітньому конгресі у США з проблем використання рослинних білків для харчових та кормових цілей люпин був охарактеризований як важливий резерв білкових речовин високої якості (Arsenieva et al., 2003). В корінні дивосилу виявлено інулін (до 44\%), інуленін, псевдоінулін, оцтову і бензойну кислоти (Kutsyk, 2013). Відомо, що інулін має здатність виводити 3 організму радіонукліди і важкі метали, стимулює зростання кісткової тканини, засвоєння кальцію в організмі людини (Paska and Masliichuk, 2016). Тому розробка м'ясних посічених напівфабрикатів 3 вмістом люпину та дивосилу є актуальною на сьогодення.

\section{Матеріал і методи досліджень}

Досліди з вивчення токсичності сировини та виробів було проведено на білих мишах з використанням відповідних методик, що базуються на екстракції токсичних речовин з сировини та виробів, за умов внутрішньошлункового введення, та згодуванням котлет з 10\% люпиновим борошном та $0,5 \%$ дивосилу протягом 10 днів.

На білих мишах було проведено вивчення токсичності люпинового борошна, кореня дивосилу та функціональних котлет що містять у складі 5\%, 10\%, $15 \%$ люпинового борошна із заміною м'ясної частини та $0,5 \%$ дивосилу, як пряно-ароматичної добавки згідно «Методики визначення токсичності шротів, жмихів i кормових дріжджів» (затверджена 28.12.1979 року). Метод базується на екстракції токсичних речовин з кормів та круп; токсини, за умов внутрішньо-шлункового введення, викликають геморагічне запалення шлунково-кишкового тракту, або загибель мишей (Kosenko et al., 1999; Kotsiumbas et al., 2006).

Згідно даної методики наважку сировини вагою 100 г засипали в колбу з притертим корком, заливали ацетоном (300 мл) і екстрагували при струшуванні на шутель-апараті 3 години. Екстракт фільтрували через паперові фільтри в чашку для випарювання і додавали до нього 2,5 мл соняшникової олії. Випаровували ацетон на водяній бані при температурі $50{ }^{\circ} \mathrm{C}$ під витяжною шафою до зникнення запаху ацетону.

Для досліду використали по 5 білих мишей масою 19-21 г, яких тримали на голодній дієті 5 годин і яким за допомогою зонда вводили одноразово через рот в шлунок 0,5 мл екстракту.

Контрольній групі білих мишей (5 голів) вводили олію, яка використовувалась для розведення екстракту. Через 3 доби спостереження, білих мишей присипали (хлороформом) і проводили патологоанатомічний розтин.

Токсичність оцінювали за такими критеріями:

- Люпинове борошно, дивосил та функціональні котлети не токсичні - миші живі, на розтині у забитих тварин патологоанатомічних змін не виявлено;

- Люпинове борошно, дивосил та функціональні котлети слаботоксичні - миші живі, на розтині у вби- 
тих тварин виявляють геморагічне запалення шлунково-кишкового тракту, частіше вогнищеве;

- Люпинове борошно, дивосил та функціональні котлети токсичні - гинуть всі, або хоч одна біла миша i на розтині загинувших і вбитих тварин спостерігають геморагічне запалення шлунково-кишкового тракту, яке в більшості випадків супроводжується дегенерацією печінки, нирок або крововиливами в паренхіматозні органи.

Визначення токсичності функціональних котлет, що містять $10 \%$ люпинового борошна із заміною м'ясної частини та 0,5\% кореня дивосилу, як пряноароматичну добавку згідно «Методики визначення токсичності на лабораторних тваринах» проводили методом згодовування готових котлет білим мишам масою 20-23 г (Kosenko et al., 1999). Котлети вводили в добовий раціон, кількісно замінюючи ними корм у складі раціону. Згодовування проводили 10 днів поспіль. Миші перед дослідом витримували 5 годин без корму (воду не обмежували). Для досліду взяли 20 тварин (10 контрольних) за якими вели щоденні клінічні спостереження.

Показниками токсичності є: втрата живої маси, розлади шлунково-кишкового тракту і центральної нервової системи (пригнічення чи збудження, порушення координації рухів, судоми параліч). Якщо після згодовування за 10 днів загибель піддослідних тварин не наступає, то їх забивають і проводять патологоанатомічні дослідження, а також ми провели гематологічні дослідження крові білих мишей. При отруєнні виявляють наявність катарального запалення шлунковокишкового тракту, крововиливи, а також дегенеративні зміни паренхіматозних органах.

\section{Результати та їх обговорення}

При вивченні токсичності люпинового борошна, дивосилу та функціональні котлети загибелі білих мишей протягом трьох діб не спостерігали.

При патологоанатомічному розтині у приспаних хлороформом тварин, яким вводили люпинове борошно, встановлено: шерстний покрив блискучий, гладенький, пошкодження відсутні, природні отвори закриті, без виділень; при внутрішньому огляді підшкірна жирова клітковина добре розвинута. Розміщення внутрішніх органів грудної і черевної порожнин анатомічно правильні; печінка темно-вишневого кольору, краї гострі, пружної консистенції з поодинокими вогнищами світлого кольору; селезінка правильної форми, темно-червого кольору, краї гострі, характерної структури на розрізі, не збільшена; нирки бобовидної форми, наявна жирова капсула, темновишневого кольору, пружної консистенції, не збільшені, границя між кірковою та мозковою зонами збережена; легені пухкої консистенції, блідо-рожевого кольору, без видимих макроскопічних змін; серце конусовидної форми, міокард темно-червоний, пружний; підшлункова блідо-рожевого кольору, часточкової будови, без видимих макроскопічних змін; шлунок заповнений кормовими масами, слизова оболонка світло-рожевого кольору, гладенька, блискуча, дещо сухувата; тонкий та товстий кишечник нерівномірно заповнений кормовими масами, слизова оболонка гладенька, блискуча, волога.

У приспаних хлороформом тварин, яким вводили дивосил при патологоанатомічному розтині встановлено: шерстний покрив блискучий, гладенький, пошкодження відсутні, природні отвори закриті, без виділень. Розміщення внутрішніх органів грудної і черевної порожнин анатомічно правильне; печінка темновишневого кольору, краї гострі; селезінка правильної форми, темно-червого кольору, краї гострі, характерної структури на розрізі, не збільшена; нирки бобовидної форми, наявна жирова капсула, темно-вишневого кольору, пружної консистенції, не збільшені, границя між кірковою та мозковою зонами збережені; легені пухкої консистенції, блідо-рожевого кольору; серце конусовидної форми, міокард темно-червоний, пружний; підшлункова блідо-рожевого кольору, часточкової будови, без видимих макроскопічних змін; шлунок помірно заповнений кормовими масами; тонкий кишечник заповнений кормовими масами, петлі кишок однорідні, без здуття, судини брижі слабо візуалізуються; товстий кишечник заповнений каловими масами характерної форми та консистенції; слизова оболонка шлунка, товстих та тонких кишок гладенька, блискуча, волога, без нашарування.

У приспаних хлороформом тварин, яким вводили витяжку котлет з 5\% люпиновим борошном та 0,5\% дивосилом при патологоанатомічному розтині виявили: зміни шерстного покриву, видимих слизових оболонок та природних отворів відсутні. Розміщення внутрішніх органів грудної і черевної порожнини анатомічно правильне; печінка однорідна, темночервоного кольору, краї гострі, характерної структури на розрізі; селезінка 3 гострими краями, темновишневого кольору, однорідна, характерна структура на розрізі збережена, краї розрізу сходяться; нирки бобовидної форми, наявна жирова капсула, темновишневого кольору, пружної консистенції, не збільшені, границя між кірковою та мозковою зонами збережені; легені пухкої консистенції, блідо-рожевого кольору, без видимих макроскопічних змін; серце конусовидної форми, міокард темно-червоний, пружний; підшлункова блідо-рожевого кольору, часточкової будови, без видимих макроскопічних змін; шлунок незначно заповнений кормовими масами, слизова оболонка без видимих змін, тонкий відділ кишечника помірно заповнений, вмістиме однорідне; вмістиме товстого кишечника пастоподібної консистенції, 3 характерним запахом. слизова оболонка тонких та товстих кишечників блідо-рожева, гладенька, блискуча, волога, без нашарувань.

У приспаних хлороформом тварин, яким вводили витяжку котлет з 10\% люпиновим борошном та 0,5\% дивосилом на патологоанатомічному розтині виявлено: розміщення внутрішніх органів грудної і черевної порожнини анатомічно правильне; спостерігали венозний застій у паренхіматозних органах; печінка однорідна, темно-червоного кольору, краї гострі, характерної структури на розрізі; селезінка з гострими краями, темно-вишневого кольору, однорідна, характерної структури на розрізі, краї розрізу сходяться; нирки бобовидної форми, наявна жирова капсула, темно- 
вишневого кольору, пружної консистенції, не збільшені, границя між кірковою та мозковою зонами збережені; легені пухкої консистенції, блідо-рожевого кольору, без змін; серце конусовидної форми, міокард темно-червоний, пружний; підшлункова блідорожевого кольору, часточкової будови, без видимих макроскопічних змін; шлунок характерної форми, петлі кишок рівномірно розміщені, без вздуття, помірно заповнені вмістимим; слизова оболонка тонких та товстих кишок блідо-рожевого кольору, гладенька, блискуча, волога.

У приспаних хлороформом тварин, яким вводили витяжку котлет з 15\% люпиновим борошном та $0,5 \%$ дивосилом на патологоанатомічному розтині встановлено: шерстний покрив блискучий, гладенький, пошкодження відсутні, природні отвори закриті, без виділень; при зовнішньому огляді розміщення внутрішніх органів грудної і черевної порожнин анатомічно правильні; спостерігали застій судин брижі; печінка пружної консистенції, однорідна, темно-червоного кольору, краї гострі, характерної структури на розрізі; селезінка з гострими краями, темно-вишневого кольору, однорідна, характерної структури на розрізі; нирки бобовидної форми, наявна жирова капсула, темновишневого кольору, пружна консистенція, не збіль- шені, границя між кірковою та мозковою зонами збережені; легені пухкої консистенції, блідо-рожевого кольору; серце конусовидної форми, міокард темночервоний, пружний; підшлункова блідо-рожевого кольору, часточкової будови, без видимих макроскопічних змін; шлунок добре заповнений; тонкий кишечник заповнений кормовими масами; пряма кишка містить сформовані калові маси характерної форми, процеси бродіння відсутні; слизова оболонка тонких і товстих кишок блідо-рожевого кольору, гладенька, блискуча, волога, без нашарувань.

Протягом дослідження у мишей, що знаходились на стандартному раціоні (контрольна група) та у тварини що отримували готові котлети не відмічено змін у поведінці, тварини були активні, без ознак зовнішньої агресії. Збереженість тварин була на рівні 100\%. При патологоанатомічному розтині макроскопічних змін в органах і тканинах не виявлено, Р > 0,05, що є в межах норми (табл. 1).

Гематологічні дослідження проводили в лабораторії клініко-біологічних досліджень ДНДКІ ветеринарних препаратів та кормових добавок. Результати досліджень представлені у таблицях 2-4, де № 1-3 проби контрольної групи, № 4-6 проби піддослідної групи мишей. Результати в межах норми.

\begin{tabular}{|c|c|c|c|c|c|c|c|}
\hline Група & & Печінка & Легені & Серце & Селезінка & Нирки & Маса тіла \\
\hline \multirow{3}{*}{ Контроль } & 1 & 0,92 & 0,50 & 0,07 & 0,09 & 0,32 & 22,2 \\
\hline & 2 & 0,99 & 0,38 & 0,09 & 0,12 & 0,34 & 21,8 \\
\hline & 3 & 0,92 & 0,28 & 0,11 & 0,19 & 0,36 & 19,5 \\
\hline \multicolumn{2}{|c|}{$\mathrm{M} \pm \mathrm{m}$} & $0,94 \pm 0,02$ & $0,38 \pm 0,07$ & $0,09 \pm 0,01$ & $0,13 \pm 0,03$ & $0,34 \pm 0,01$ & $21,17 \pm 0,84$ \\
\hline \multirow{3}{*}{ Дослідна } & 4 & 1,17 & 0,24 & 0,13 & 0,19 & 0,38 & 23,0 \\
\hline & 5 & 1,04 & 0,21 & 0,10 & 0,15 & 0,25 & 20,0 \\
\hline & 6 & 1,38 & 0,30 & 0,13 & 0,20 & 0,31 & 21,7 \\
\hline \multirow{2}{*}{\multicolumn{2}{|c|}{$\mathrm{M} \pm \mathrm{m}$}} & $1,2 \pm 0,1$ & $0,25 \pm 0,03$ & $0,12 \pm 0,01$ & $0,18 \pm 0,02$ & $0,31 \pm 0,04$ & $21,57 \pm 0,87$ \\
\hline & & $\mathrm{P}>0,05$ & $\mathrm{P}>0,05$ & $\mathrm{P}>0,05$ & $P>0,05$ & $\mathrm{P}>0,05$ & $\mathrm{P}>0,05$ \\
\hline
\end{tabular}

Морфологічні показники крові мишей

\begin{tabular}{|c|c|c|c|c|c|c|c|}
\hline $\begin{array}{c}\text { № п/п } \\
\text { проби }\end{array}$ & $\begin{array}{c}\text { Еритроцити, } \\
\text { Т/л }\end{array}$ & $\begin{array}{c}\text { Гемоглобін, } \\
\text { Г/л }\end{array}$ & $\begin{array}{c}\text { Гематокрит, } \\
\text { \% }\end{array}$ & $\begin{array}{c}\text { МСH, } \\
\text { Пг }\end{array}$ & $\begin{array}{c}\text { МСНС, } \\
\text { Г/дл }\end{array}$ & $\begin{array}{c}\text { МСV, } \\
\text { мкм }^{3}\end{array}$ & $\begin{array}{c}\text { Тромбоцити, } \\
\text { Г/л }\end{array}$ \\
\hline 1 & 8,2 & 147 & 41 & 17,8 & 35,2 & 50,7 & 669 \\
\hline 2 & 7,2 & 193 & 34 & 26,8 & 57,1 & 46,9 & 442 \\
\hline 3 & 7,8 & 126 & 37 & 16,0 & 33,8 & 47,4 & 794 \\
\hline 4 & 7,8 & 137 & 38 & 17,1 & 36,0 & 47,7 & 538 \\
\hline 5 & 9,1 & 143 & 40 & 15,6 & 35,5 & 44,1 & 971 \\
\hline 6 & 7,3 & 118 & 35 & 16,1 & 33,5 & 48,2 & 914 \\
\hline
\end{tabular}

Вміст лейкоцитів та лейко грама крові мишей

Таблиияя 3

\begin{tabular}{|c|c|c|c|c|}
\hline \multirow{2}{*}{$\begin{array}{c}\text { № п/п } \\
\text { проби }\end{array}$} & \multirow{2}{*}{ Лейкоцити, г/л } & \multicolumn{3}{|c|}{ Лейкограма,\% } \\
\cline { 3 - 5 } & & Лімфоцити, $\%$ & Моноцити, $\%$ & Гранулоцити, \% \\
\hline 1 & 8,4 & 69,8 & 10,5 & 19,7 \\
\hline 2 & 8,2 & 64,7 & 9,0 & 26,3 \\
\hline 3 & 7,8 & 71,0 & 11,0 & 18,0 \\
\hline 4 & 8,9 & 66,3 & 11,2 & 22,5 \\
\hline 5 & 5,9 & 75,7 & 6,1 & 18,2 \\
\hline 6 & 5,8 & 76,2 & 13,2 & 10,6 \\
\hline
\end{tabular}


Біохімічні показники сироватки крові мишей

\begin{tabular}{|c|c|c|c|c|c|c|c|c|}
\hline $\begin{array}{l}\text { № п/п } \\
\text { проби }\end{array}$ & Заг.білок, г/л & $\begin{array}{c}\text { Креатинін, } \\
\text { мкмоль/л }\end{array}$ & $\begin{array}{c}\text { Сечовина, } \\
\text { ммоль/л }\end{array}$ & АсАт, Од/л & АлАт, Од/л & $\begin{array}{l}\text { ЛФ, } \\
\text { Од/л }\end{array}$ & $\begin{array}{c}\text { Альфа- } \\
\text { амілаза, } \\
\text { Од/л }\end{array}$ & $\begin{array}{c}\text { Глюкоза, } \\
\text { ммоль/л }\end{array}$ \\
\hline 1 & 6,07 & 46,9 & 7,6 & 243,2 & 52,6 & 663,5 & 1652 & 5.40 \\
\hline 2 & 6,45 & 48,5 & 6,3 & 237,6 & 48,6 & 258,6 & 2113 & 5,16 \\
\hline 3 & 7,10 & 42,7 & 8,5 & 227,7 & 55,1 & 443,9 & 1821 & 4,67 \\
\hline 4 & 6,02 & 37,7 & 8,8 & 255,5 & 61,1 & 479,5 & 2075 & 4,47 \\
\hline 5 & 5,25 & 47,7 & 8,5 & 253,1 & 52,3 & 385,1 & 1781 & 5,08 \\
\hline 6 & 5.47 & 41,8 & 7,9 & 275,1 & 49,7 & 516,6 & 1943 & 6,29 \\
\hline
\end{tabular}

\section{Висновки}

В результаті проведених досліджень встановлено, люпинове борошно, корінь дивосилу та функціональні котлети, що містять у складі 5, 10, 15\% люпинового борошна із заміною м'ясної частини на 0,5\% дивосилу, як пряно-ароматичної добавки - не викликають катарального або геморагічного запалення шлунково-кишкового тракту, та загибель мишей, отож є не токсичні. При згодовуванні мишам котлет з 10\% вмістом люпинового борошна та $0,5 \%$ дивосилу встановлено, що при патологоанатомічному розтині макроскопічних змін в органах і тканинах не виявлено, $\mathrm{P}>0,05$, що $\epsilon$ в межах норми та гематологічні дослідження крові мишей підтверджують, що даний продукт можна включати в раціон харчування людей.

Тому люпинове борошно та дивосил рекомендовано вводити у функціональні продукти, для вирішення проблеми білкового дефіциту та повноцінног, лікувально-профілактичного харчування.

\section{Бібліографічні посилання}

Arsenieva, L.Iu., Bondar, N.P., Holovchenko, O.V. (2003). Vykorystannia nasinnia liupynu dlia vyrobnytstva vysokobilkovykh kharchovykh produktiv. Visnyk DonDUET. 1(17), 79-83 (in Ukrainian).

Kutsyk, T.P. (2013). Novyi funktsionalnyi kyslomolochnyi produkt «Dyvosyl». Doslidna stantsiia likarskykh roslyn ISHPS NAAN, Ukraina. Kh.: Vyd-vo «ESEN», 149-151 (in Ukrainian).

Paska, M., Masliichuk, O. (2016). Mikrobiolohichna ta spozhyvcha kharakterystyka miasnykh posichenykh napivfabrykativ z dodavanniam liupynovoho boroshna ta dyvosylu. Naukovyi visnyk LNUVMBT im. S.Z. Hzhytskoho. 18(4), 121-123 (in Ukrainian).

Kosenko, M.V., Kotsiumbas, I.Ya., Velychko, V.O. (1999). Toksykolohichnyi kontrol kormiv ta kormovykh dobavok: Metodychni rekomendatsii. Lviv: Triada plius (in Ukrainian).

Kotsiumbas, I.Ya., Malyk, O.H., Patereha, I.P. (2006). Doklinichni doslidzhennia veterynarnykh likarskykh zasobiv. Lviv: Triada plius (in Ukrainian).

Стаття надійшла до редакиії 13.03.2017 